\title{
ASSESSMENT OF THE SINGLE SHOT HIT PROBABILITY AS A FUNCTION OF THE HORIZONTAL RANGE TAKING INTO ACCOUNT DIFFERENT TARGET TYPES AND POINTS OF AIM
}

\author{
Vadim L. Khaikov \\ independent researcher, Krasnodar, Russian Federation, \\ e-mail: wadimhaikow@inbox.ru, \\ ORCID iD: (Dhttp://orcid.org/0000-0003-1433-3562
}

DOI: 10.5937/vojtehg67-18522; https://doi.org/10.5937/vojtehg67-18522

FIELD: Applied Mathematics, Operations Research

ARTICLE TYPE: Original Scientific Paper

ARTICLE LANGUAGE: English

\section{Abstract:}

This article presents a method for assessing the hit probability for stationary shooting targets as a function of the projectile horizontal range (PHR), the target type and the point of aim (POA) location. The proposed procedure consists of three blocks. Block I is devoted to the double integral formula taking into account changes in the point of impact (POI) location as a function of the PHR. The characteristics of bullet accuracy and precision versus the PHR are determined in block II. The basis of blocks I and II is the bi-variate uncorrelated Laplace-Gauss probability distribution. The functions of the POI location (ordinate/abscissa) versus the PHR and the functions of the characteristics of the bullet dispersion versus the PHR are represented in the form of polynomials. The description of the target silhouette contour is given in block III. Mathematically, the target contour is a piecewise function which defines the upper and lower edges of the shooting target and it also represents the limit for the double integral formula of block 1 . The proposed method is built on a modular basis and allows a user to change types of weapons and shooting targets. For demo calculations, the accuracy and precision characteristics of the $5.45 \times 39$ Kalashnikov assault rifle model MPi AK-74N were selected. Five types of Swiss military targets imitating an OPFOR combatant's silhouette were used as shooting targets. For illustrating the operability of the proposed method, the hit probabilities for the $K, H, G, F$, and $E$ shooting targets were evaluated for the PHR from 50 to $400 \mathrm{~m}$. All computations are implemented in the PTC Mathcad v.15.

Key words: hit probability, numerical solution, shooting target, double integrals, bullet dispersion, horizontal range, Mathcad. 


\section{Introduction}

Estimation of the hit probability is an important part of the shooting effectiveness assessment (Rodney, 2012), (Svateev, 2013), (Svateev, 2014), (Peelen, 2017), (Wollschläger, 2017). In (Khaikov, 2018), we show how to estimate the single shot hit probability by shooting to a fixed target with an arbitrary contour form owing to a numerical solution of the double integral. During the calculation process, the following parameters are set: the position of the mean point of impact $(P O I)$ and the characteristics of the bullet dispersion ellipse. However, during firing, there is uncertainty about the horizontal range to the selected target; it is also necessary to have a priori information about the change in the hit probability for the interval from the minimum to the maximum distances.

Since the position of the dispersion center and the dispersion characteristics are the functions of the projectile horizontal range $(P H R)$, the hit probability can be expressed as a function of the «target-shooter» distance ${ }^{1}$.

The aim of this contribution is to show how to calculate the hit probability $\left(P_{h i t}\right)$ as a function of the $P H R$ with respect to different target types and the location of the $P O A$. As a result, we get not only one (or a point) estimation of the $P_{\text {hit }}$ for a single (selected) value of the horizontal range, but also a change of this parameter within a certain distance interval. As in (Khaikov, 2018), all calculations will be implemented in the computer algebra system (CAS) Mathcad v.15.

In order to make the estimations original and more diverse, we will use here Swiss military targets and the external ballistics of the $5.45 \times 39$ Kalashnikov assault rifle model MPi AK-74N². The information about this firearm can be found in (NVA der DDR, 1985), (TRADOC, 1975, 2015), (http://weaponland.ru, nd).

\section{Creating a mathematical model}

Let us assume that the attacking opposing force (OPFOR) is represented by running or lying combatants whose silhouettes can be replaced by plane (or 2D) shooting targets with a certain equivalent area $^{3}$

\footnotetext{
In this article, the expressions "the target-shooter distance" and "the projectile horizontal range" are synonymous.

$2 \mathrm{MPi}$ AK-74N - (in German) Mashinenpistole-Automat Kalaschnikow AK-74 für Nachtsichtgerat. Assault rifles MPi AK-74N were manufactured on "VEB Fahrzeug und Waffenfabrik Ernst Thälmann", Suhl (Thuringia).

3 As a rule, shooting targets are a set of geometric primitives: rectangles, trapezoids, triangles, and squares.
} 
(Fig. 1a). Human silhouette targets of different types are used for military and police firearms training. More schematized targets are applied for firearm sports competitions.

Let it be necessary to estimate the hit probability for several targets at the distances $x_{1}, x_{I I}$, and $x_{I I I}$ (Fig. 1b). All shooting targets at different distances are the same and in Fig. $1 \mathrm{~b}$ they are rotated for 90 degrees counter-clockwise. The targets are rotated only for the simplicity of visualization.

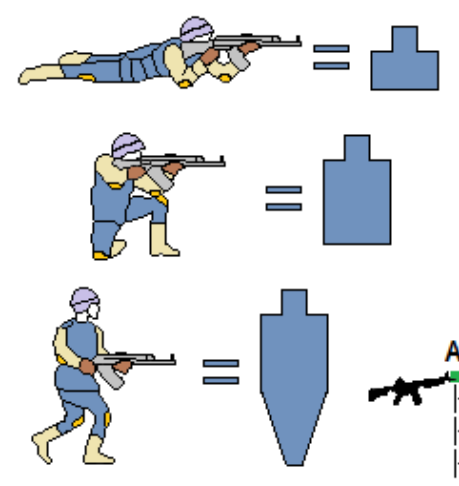

a)



b)

Figure 1 - Replacement of combatant silhouettes with shooting targets (a) and the change in the POI location and the characteristics of the dispersion ellipse as a function of the PHR (b)

Puс. 1 - Замена силуэтов комбатантов в виде стрелковых мишеней (a) и изменение местоположения СТП и характеристик эллипса рассеивания в зависимости от горизонтальной дальности «стрелок - мишень» (b)

Слика 1 - Замена силуета војника у облику мета за гађање (а) и промена локација тачака погодака (ТП) и карактеристика елипсе дисперзије у зависности од хоризонталног растојања између стрелца и мете (ХPM) (б)

When firing at a shooting target, depending on the $P H R$, the mean bullet (ballistic) trajectory ${ }^{4}$ will pass through the target or above (below) it (Fig. 1). The difference in the PHR between the shooter and the shooting target $\left(\mathrm{x}_{\mathrm{I}}, \mathrm{x}_{\mathrm{II}}, \mathrm{x}_{\mathrm{III}}\right)$ determines the difference in the $\mathrm{POI}$ location and the constantly increasing parameters of the dispersion ellipse for each target. The location of the POA in Fig. 1 is not indicated.

\footnotetext{
${ }^{4}$ This trajectory is a projectile path obtained by theoretical calculation and agreed upon with experimental shooting tests. In this way, the mean ballistic trajectory $(M B T)$ is the space curve near which the remaining trajectories are grouped taking into account the regularity of bullet dispersion.
} 
Let us define that the shooting mode (single shots) and the aiming parameters are not changed by shooting. The ABCD curve (Fig. 1b) is the mean ballistic trajectory $(M B T)$ with respect to the specified angle of departure (or number/clicks of sight) and the previously specified zero range. Uncertainty in the PHR magnitude is transformed into a vertical projectile dispersion at a chosen shooting target. Naturally, the hit probability value ( $P_{\text {hit }}$ I, $\left.P_{\text {hit II }}, P_{\text {hit III }}\right)$ will change with the variations of the $P O I$ location and with the change in the dispersion ellipse characteristics ${ }^{5}$.

The mathematical model of the hit-probability vs the PHR will consist of three blocks. Block I will be devoted to the double integral formula taking into account the changes in the POI location and bullet dispersion. Block II will include the bullet dispersion characteristics vs the horizontal range. Finally, block III will describe the functions of a target silhouette contour.

Block I. This block of the mathematical model is based on the results of (Khaikov, 2018). If the $T$ region (letter " $T$ " means a target) is a plane figure, and the hit probability of random variables $Z$ and $Y$ is determined by the 2D uncorrelated Laplace-Gauss distribution $f(z, y)$, then the target hit probability is defined by formula (1) (Venttsel', 2006, p.196)

$$
P[(Z, Y) \subset T]=\iint_{T} f(z, y) d z d y
$$

where: $T$ - the region of integration in the zy-plane; $z, y$ - the Cartesian coordinates; $\sigma_{z}, \sigma_{y}$ - the standard deviation of the continuous random variables $Z, Y ; m_{z}, m_{y}$ - the coordinates of the center of dispersion (the mean of $Z$ and $Y$ ) or the $P O I$, since it is the same one; $f(z, y)$ - the integrand and the uncorrelated bi-variate Laplace-Gauss distribution (2):

5 The first important factor is the type of weapon and the type of cartridge used. In the second place, the POI location depends on the target type. For the pre-selected weapon, the cartridge and the shooting target, the $P O I$ location and the characteristics of the dispersion ellipse are the functions of the PHR. In the case under consideration, skills of the shooter and combat stress as psychophysical conditions are not taken into account. 


$$
f(z, y)=\frac{1}{2 \pi \sigma_{z} \sigma_{y}} \exp \left(-\left[\frac{\left(z-m_{z}\right)^{2}}{2 \sigma_{z}^{2}}+\frac{\left(y-m_{y}\right)^{2}}{2 \sigma_{y}^{2}}\right]\right)
$$

In (Khaikov, 2018, pp.739-756), it is shown that if the target silhouette is described by two functions (the function of the bottom contour line of the target $\varphi_{1}(z)$ and the function of the upper line of the target's contour) $\varphi_{2}(z)$ and two constants $a$ and $b(a<b)$, then the hit probability can be expressed as

$$
P[(Z, Y)]=\int_{a}^{b} \int_{\varphi_{1}(z)}^{\varphi_{2}(z)} \frac{1}{2 \pi \sigma_{z} \sigma_{y}} \exp \left(-\left[\frac{\left(z-m_{z}\right)^{2}}{2 \sigma_{z}^{2}}+\frac{\left(y-m_{y}\right)^{2}}{2 \sigma_{y}^{2}}\right]\right) d z d y .
$$

If in formula (3) the constants $m_{z}, m_{y}, \sigma_{z}, \sigma_{y}$ are transformed into functions that depend on the distance $x$ "shooter - target" $\left(m_{z}(x)\right.$, $\left.m_{y}(x), \sigma_{z}(x), \sigma_{y}(x)\right)$, we get a formula that realizes the transition from $P[(Z, Y)]$ to $P[(Z, Y, X)]$

$$
P[(Z, Y, X)]=\int_{a}^{b} \int_{\varphi_{1}(z)}^{\varphi_{2}(z)} \frac{1}{2 \pi \sigma_{z}(x) \sigma_{y}(x)} \exp \left(-\left[\frac{\left(z-m_{z}(x)\right)^{2}}{2 \sigma_{z}(x)^{2}}+\frac{\left(y-m_{y}(x)\right)^{2}}{2 \sigma_{y}(x)^{2}}\right]\right) d z d y .
$$

The method of determining the functions $m_{z}(x), m_{y}(x), \sigma_{z}(x)$, and $\sigma_{y}(x)$ for the assault rifle MPi AK-74N will be described in block II.

Block II. Characteristics of $m_{z}(x), m_{y}(x), \sigma_{z}(x), \sigma_{y}(x)$ functions.

The trajectories of the steel core bullet of the $5.45 \times 39$ Kalashnikov cartridge (bullet weight - $3.4 \mathrm{~g}$; muzzle velocity - $960 \mathrm{~m} / \mathrm{s}$ ) under the line of departure and over/under the line of sight for mechanical sight from 1 to 10 are described in (NVA der DDR, 1985, pp.90-93) as tabulated data. Let us visualize this table and obtain the approximation formula (Fig. 2).

The data corresponding to sight number 3 (NVA der DDR, 1985, pp.90-93) can be approximated using a polynomial. As a result, we obtain the function

$$
m_{y}=-0.029+1.969 \cdot 10^{-3} x-2.645 \cdot 10^{-6} x^{2}-1.192 \cdot 10^{-8} x^{3},
$$


where $x$ is the PHR («shooter-target» distance) in meters (50 $\leq \mathrm{x} \leq 400$ $\mathrm{m})$ and $m_{y}$ is the ballistic trajectory profile in meters for the sight setting 3 (position 3 for standard mechanical sight of the Kalashnikov assault rifle). The red curve in Fig. 2 shows the change of the POI height. At $50 \mathrm{~m}$, shots will be about 6 centimeters $=0.06 \mathrm{~m}$ high. The vertex of the flight path is $27.66 \mathrm{~cm}=0.267 \mathrm{~m}$, observed for the PHR $168.3 \mathrm{~m}$ (Fig. 2a). The zero distance is $300 \mathrm{~m}$. Beyond $300 \mathrm{~m}(P H R>300 \mathrm{~m})$, the bullet trajectory will drop rapidly to about 43 centimeters $\approx 0.427 \mathrm{~m}$ low at $400 \mathrm{~m}$.

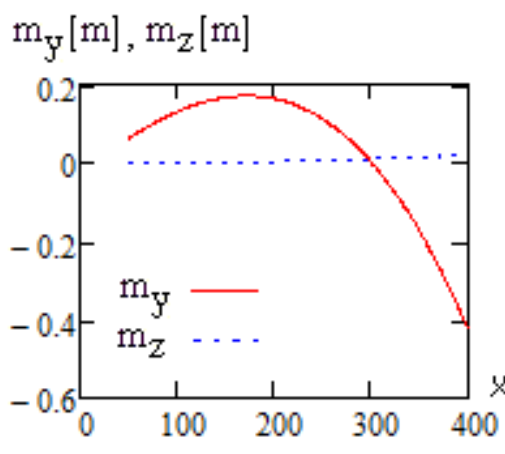

a)



b)

Figure 2-Characteristics of the location of the center of dispersion (a) and the characteristics of the dispersion ellipse (b) as a function of the PHR

Puc. 2 - Характеристики положения центра рассеивания (a) и эллипса рассеивания (b) как фуункция дистанции до цели

Слика 2 - Карактеристике положаја центра дисперзије (а) и карактеристике елипсе дисперзије (б) у фуункцији растојања до мете

The right-hand bullet drift or the bias of the $P O I$ to the right side due to the bullet gyroscopic stabilization can be expressed by the polynomial model

$$
m_{z}=-1.667 \cdot 10^{-5} x+1.667 \cdot 10^{-7} x^{2},
$$

where $x$ is the PHR in meters $(50 \leq \mathrm{x} \leq 400 \mathrm{~m})$ and $m_{z}$ is the right-hand bullet drift in meters (the blue dotted curve in Fig. 2a).

The bullets dispersion in the vertical $\left(\sigma_{y}\right)$ and the lateral directions $\left(\sigma_{z}\right)$ in the form of standard deviation are expressed as two polynomial functions PHR-argument (Fig. 2b)

$$
\sigma_{y}=5.935 \cdot 10^{-4} x
$$




$$
\sigma_{z}=2.967 \cdot 10^{-4} x
$$

where $x$ is the PHR in meters $(50 \leq \mathrm{x} \leq 400 \mathrm{~m})$, and $\sigma_{y}$ and $\sigma_{z}$ represent the standard deviation in meters.

Thus, two functions $\left(\sigma_{y}(x)\right.$ and $\left.\sigma_{z}(x)\right)$ determine the shape of the dispersion ellipse and two more, i.e. $m_{y}(x), m_{z}(x)$, determine the locations of the dispersion center versus the PHR from 50 to $400 \mathrm{~m}$.

In order to use formula (4), we need to determine the functions $\varphi_{1}(z), \varphi_{2}(z)$ and the constants $a$ and $b$.

Block III. Functions of the target silhouette contour $\varphi_{1}(z)$ and $\varphi_{2}(z)$.

Depending on an OPFOR combatant silhouette seen by a shooter, there are «head», "head-shoulders», «head-burst», "head-hip», and «man sized» military targets (Fig. 3$)^{6}$.

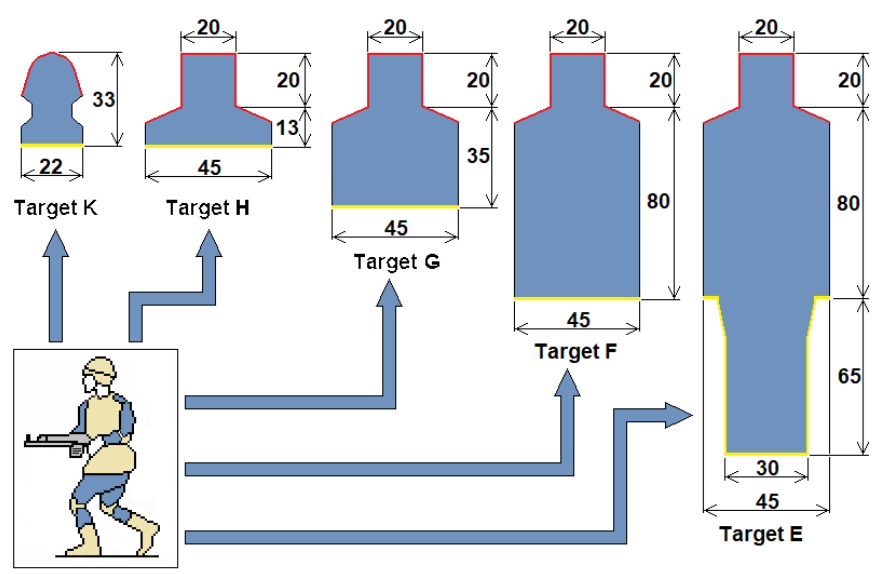

Figure 3 - Military shooting targets (cibles de campagne): $K, H, G, F$, and $E$ Puc. 3-Армейские мишени K, H, G, F, E для стрельб Слика 3 - Војне мете за гађање K, H, G, Fu E

Among the five shooting targets, the $K$ and $H$ targets have the minimum height of 33 centimeters $(0.33 \mathrm{~m})$; conversely, the $E$ target has the maximum height of $1.65 \mathrm{~m}$. The target area is increased in the

6 in comparison with Fig. 1, the number of types of targets in Fig. 3 was increased from 3 to 5 . In different countries, shooting targets of the same type (for example, the $K$ target «head in a protective helmet» or the $E$ target «man sized target») may have different shapes and different geometric areas. These characteristics are determined in individual countries by their armed forces regulations. 
direction from $K$ to $E$. The $K, H, G, F$, and $E$ human silhouette targets ${ }^{7}$ are used in the armed forces of the Swiss Confederation for shooting training (http://www.wikiwand.com, nd).

The target contour can be designated in two ways (Khaikov, 2018, pp.739-756): in option I, the upper (lower) contour should be identified as the $y(z)$ functions or, in option II, the right (left) contour should be identified as the $z(y)$ curves. For all five targets in Fig. 3, the upper contour lines $(U C L)$ are red, and the bottom counter lines $(B C L)$ are yellow. If we consider the UCL of the target $K$, then we use the notation $U C L_{K}$. This procedure for the $B C L$ of the target $E$ is similar: $B C L_{E}$.

The geometry analysis and the contour lines identification for the $G$ target are shown in Fig. 4. It is a flat shooting target which can be described as the ABCDEFGHIJ polygon. The $G$ target has an axis of symmetry that passes through the EJ (Fig. 4a). The left side of the $G$ target is the ABCDEJ polygon, and the right-hand side is the EFGHIJ polygon. The areas of these polygons are the same. The presence of the right-hand bullet drift causes the $P O I$ to be located on the right side (the red ellipse in Fig. 4b ).

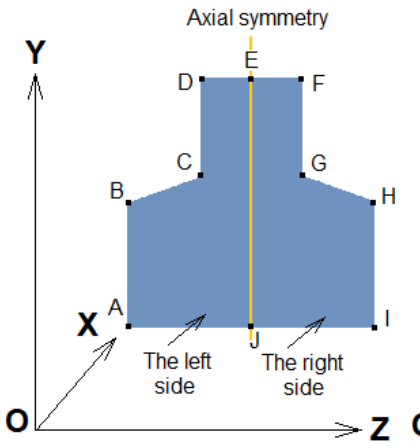

a)

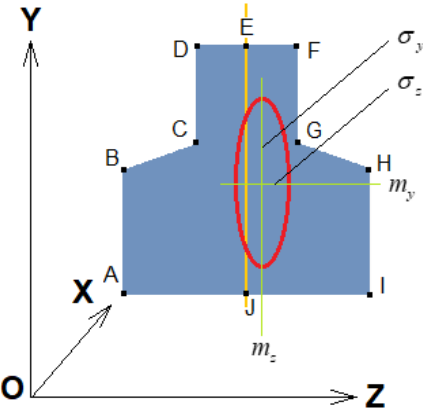

b)

Figure 4-Analysis of the geometry of the G shooting target (a). A location of the dispersion ellipse (b)

Puc. 4 - Анализ геометрии стрелковой мишени G (a). Положение эллипса рассеивания (b)

Слика 4 - Анализа геометрије мете за гађање G (а). Локација елипсе дисперзије

(б)

7 The following names are used for target designation (in German): Feldscheiben, Ordonanzscheiben, $\mathrm{K}$-Sheibe, G-Sheibe, $\mathrm{H}$-Sheibe, and so on. 
Not taking into account the symmetry of the G target, its UCL can be described as the BCDEFGH line. When symmetry is taken into account, the geometric formula of the left-hand side is BCDE. Similar reasoning applies to the description of the BCL: AJI (without symmetry) and AJ (the left side of the figure with symmetry taken into account).

It is necessary to determine the coordinates of the vertices of the ABCDEFGHIJ polygon and to obtain an analytical expression of the sides of the $G$ target. The coordinates of the points for the $G$ target contour and its analytic functions are collected in Table 1.

Table 1 - Coordinates of the points for the G target contour line

Таблица 1 - Координаты точек контура мишени типа $G$

Табела 1 - Координате тачака контуре мете типа G

\begin{tabular}{|c|c|c|c|c|}
\hline Points & $\mathrm{Z}, \mathrm{m}$ & $\mathrm{Y}, \mathrm{m}$ & $\begin{array}{c}\text { Boundary } \\
\text { points of line }\end{array}$ & Analytic function \\
\hline $\mathrm{A}$ & -0.225 & 0.0 & $\mathrm{~A}-\mathrm{B}$ & $\mathrm{z}(\mathrm{y})=-0.225$ \\
\hline $\mathrm{B}$ & -0.225 & 0.302 & $\mathrm{~B}-\mathrm{C}$ & $\mathrm{y}(\mathrm{z})=0.384^{\star} \mathrm{z}+0.388$ \\
\hline $\mathrm{C}$ & -0.1 & 0.35 & $\mathrm{C}-\mathrm{D}$ & $\mathrm{z}(\mathrm{y})=-0.1$ \\
\hline $\mathrm{D}$ & -0.1 & 0.55 & $\mathrm{D}-\mathrm{E}$ & $\mathrm{y}(\mathrm{z})=0.55$ \\
\hline $\mathrm{E}$ & 0.0 & 0.55 & $\mathrm{E}-\mathrm{F}$ & $\mathrm{y}(\mathrm{z})=0.55$ \\
\hline $\mathrm{F}$ & 0.1 & 0.55 & $\mathrm{~F}-\mathrm{G}$ & $\mathrm{z}(\mathrm{y})=0.1$ \\
\hline $\mathrm{G}$ & 0.1 & 0.35 & $\mathrm{G}-\mathrm{H}$ & $\mathrm{z}(\mathrm{z})=-0.384^{\star} \mathrm{z}+0.388$ \\
\hline $\mathrm{H}$ & 0.225 & 0.302 & $\mathrm{H}-\mathrm{I}$ & 0.225 \\
\hline $\mathrm{I}$ & 0.225 & 0.0 & $\mathrm{I}-\mathrm{J}$ & $\mathrm{y}(\mathrm{z})=0$ \\
\hline $\mathrm{J}$ & 0.0 & 0.0 & $\mathrm{~J}-\mathrm{A}$ & $\mathrm{y}(\mathrm{z})=0$ \\
\hline
\end{tabular}

The contour line $(C L) C L_{G}(z)$ of the $G$ shooting target (the $U C L$ $(\mathrm{BCDEFGH}) \cup C L_{G}(z)$ and the $\left.B C L(\mathrm{AJI}) B C L_{G}(z)\right)$ can be described by a piecewise function:

$$
C L_{\mathrm{G}}(z)=\left\{\begin{array}{l}
U C L_{\mathrm{G}}(z)=\left(\begin{array}{cc}
0.384 z+0.388 & -0.225 \leq z<-0.1 \\
0.55 & -0.1 \leq z<0.1 \\
-0.384 z+0.388 & 0.1 \leq z \leq 0.225
\end{array}\right) \\
B C L_{\mathrm{G}}(z)=\left(\begin{array}{ll}
0 & -0.225 \leq z \leq 0.225
\end{array}\right)
\end{array}\right.
$$

Since the geometry of the $G$ target has an axis of symmetry (EJ axis) and if the $P O I$ lies on the EJ axis, then the hit probabilities for the 
right and left parts are the same. If the POI location is not on the EJ axis, then the hit probabilities for the right and left parts of the $G$ target are different. The side of the target where the $P O I$ is located has a higher hit probability. In view of the fact that the bullet gyroscopic stabilization causes a shift of the POI to the right, the right-hand side of the $G$ target has a larger hit probability than the left one.

The coordinates of the points for the $H$ target contour line are collected in Table 2.

Table 2 - Coordinates of the points for the $\mathrm{H}$ target contour line

Таблица 2 - Координаты точек контура мишени типа $\mathrm{H}$ Табела 2 - Координате тачака контуре мете типа $H$

\begin{tabular}{|c|c|c|c|c|}
\hline Points & $\mathrm{Z}, \mathrm{m}$ & $\mathrm{Y}, \mathrm{m}$ & $\begin{array}{c}\text { Boundary } \\
\text { points of line }\end{array}$ & Analytic function \\
\hline $\mathrm{A}$ & -0.225 & 0.0 & $\mathrm{~A}-\mathrm{B}$ & $\mathrm{z}(\mathrm{y})=-0.225$ \\
\hline $\mathrm{B}$ & -0.225 & 0.082 & $\mathrm{~B}-\mathrm{C}$ & $\mathrm{y}(\mathrm{z})=0.384^{\star} \mathrm{z}+0.1684$ \\
\hline $\mathrm{C}$ & -0.1 & 0.13 & $\mathrm{C}-\mathrm{D}$ & $\mathrm{z}(\mathrm{y})=-0.1$ \\
\hline $\mathrm{D}$ & -0.1 & 0.33 & $\mathrm{D}-\mathrm{E}$ & $\mathrm{y}(\mathrm{z})=0.33$ \\
\hline $\mathrm{E}$ & 0.0 & 0.33 & $\mathrm{E}-\mathrm{F}$ & $\mathrm{y}(\mathrm{z})=0.33$ \\
\hline $\mathrm{F}$ & 0.1 & 0.33 & $\mathrm{~F}-\mathrm{G}$ & $\mathrm{z}(\mathrm{y})=0.1$ \\
\hline $\mathrm{G}$ & 0.1 & 0.13 & $\mathrm{G}-\mathrm{H}$ & $\mathrm{y}(\mathrm{z})=-0.384^{\star} \mathrm{z}+0.168$ \\
\hline $\mathrm{H}$ & 0.225 & 0.082 & $\mathrm{H}-\mathrm{I}$ & $\mathrm{z}(\mathrm{y})=0.225$ \\
\hline $\mathrm{I}$ & 0.225 & 0.0 & $\mathrm{I}-\mathrm{J}$ & $\mathrm{y}(\mathrm{z})=0$ \\
\hline $\mathrm{J}$ & 0.0 & 0.0 & $\mathrm{~J}-\mathrm{A}$ & $\mathrm{y}(\mathrm{z})=0$ \\
\hline Notes: The coordinates of the points are given according to Fig. 3. \\
The symmetry of the points is shown with the orange and blue background. \\
\hline
\end{tabular}

The analysis of Table 2 allows us to describe the contour needed for integrating the double integral (4) and determining the hit probability. The contour of the $H$ shooting target (the UCL (BCDEFGH) and the $B C L$ $(A \mathrm{Jl}))$ can be described by a piecewise function:

$$
C L_{\mathrm{H}}(z)=\left\{\begin{array}{c}
U C L_{\mathrm{H}}(z)=\left(\begin{array}{cc}
0.384 z+0.1684 & -0.225 \leq z<-0.1 \\
0.33 & -0.1 \leq z<0.1 \\
-0.384 z+0.1684 & 0.1 \leq z \leq 0.225
\end{array}\right) . \\
B C L_{\mathrm{H}}(z)=\left(\begin{array}{ll}
0 & -0.225 \leq z \leq 0.225
\end{array}\right)
\end{array}\right.
$$

The coordinates of the points for the $F$ target contour line are presented in Table 3. 
Table 3 - Coordinates of the points for the $F$ target contour line

Таблица 3 - Координаты точек контура мишени типа $F$

Табела 3 - Координате тачака контуре мете типа $F$

\begin{tabular}{|c|c|c|c|c|}
\hline Points & $\mathrm{Z}, \mathrm{m}$ & $\mathrm{Y}, \mathrm{m}$ & $\begin{array}{c}\text { Boundary } \\
\text { points of line }\end{array}$ & Analytic function \\
\hline $\mathrm{A}$ & -0.225 & 0.0 & $\mathrm{~A}-\mathrm{B}$ & $\mathrm{z}(\mathrm{y})=-0.225$ \\
\hline $\mathrm{B}$ & -0.225 & 0.752 & $\mathrm{~B}-\mathrm{C}$ & $\mathrm{y}(\mathrm{z})=0.384^{\star} \mathrm{z}+0.838$ \\
\hline $\mathrm{C}$ & -0.1 & 0.8 & $\mathrm{C}-\mathrm{D}$ & $\mathrm{z}(\mathrm{y})=-0.1$ \\
\hline $\mathrm{D}$ & -0.1 & 1.0 & $\mathrm{D}-\mathrm{E}$ & $\mathrm{y}(\mathrm{z})=1.0$ \\
\hline $\mathrm{E}$ & 0.0 & 1.0 & $\mathrm{E}-\mathrm{F}$ & $\mathrm{z}(\mathrm{z})=1.0$ \\
\hline $\mathrm{F}$ & 0.1 & 1.0 & $\mathrm{~F}-\mathrm{G})=0.1$ \\
\hline $\mathrm{G}$ & 0.1 & 0.8 & $\mathrm{G}-\mathrm{H}$ & $\mathrm{y}(\mathrm{z})=-0.384^{\star} \mathrm{z}+0.838$ \\
\hline $\mathrm{H}$ & 0.225 & 0.752 & $\mathrm{H}-\mathrm{I}$ & $\mathrm{z}(\mathrm{y})=0.225$ \\
\hline $\mathrm{I}$ & 0.225 & 0.0 & $\mathrm{I}-\mathrm{J}$ & $\mathrm{y}(\mathrm{z})=0$ \\
\hline $\mathrm{J}$ & 0.0 & 0.0 & $\mathrm{~J}-\mathrm{A}$ & $\mathrm{y}(\mathrm{z})=0$ \\
\hline \multicolumn{7}{|l}{ Notes: The coordinates of the points are given according to Fig. 3. } \\
The symmetry of the points is shown with the orange and blue background. \\
\hline
\end{tabular}

The contour of the $F$ shooting target (the UCL (BCDEFGH) and the $B C L$ line $(A J I))$ can be described by a piecewise function:

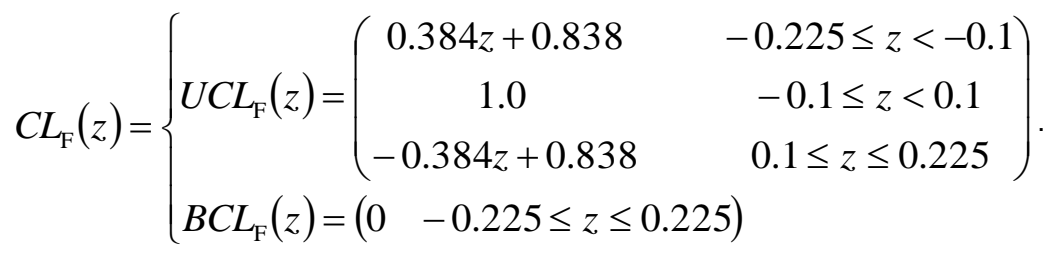

The coordinates of the points for the $E$ target contour line are listed in Table 4.

Table 4-E shooting target: coordinates of the points

Таблица 4 - Координаты точек контура мишени типа E

Табела 4-Координате тачака контуре мете типа $E$

\begin{tabular}{|c|c|c|c|c|}
\hline Points & $\mathrm{Z}, \mathrm{m}$ & $\mathrm{Y}, \mathrm{m}$ & $\begin{array}{c}\text { Boundary } \\
\text { points of line }\end{array}$ & Analytic function \\
\hline A & -0.15 & 0.0 & A-B & $\mathrm{z}(\mathrm{y})=-0.15$ \\
\hline B & -0.15 & 0.4973 & $\mathrm{~B}-\mathrm{C}$ & $\mathrm{y}(\mathrm{z})=-5.817^{*} \mathrm{z}-0.375$ \\
\hline C & -0.17625 & 0.65 & C-D & $\mathrm{y}(\mathrm{z})=0.65$ \\
\hline D & -0.225 & 0.65 & D-E & $\mathrm{z}(\mathrm{y})=-0.225$ \\
\hline E & -0.225 & 1.402 & $\mathrm{E}-\mathrm{F}$ & $\mathrm{y}(\mathrm{z})=0.384^{*} \mathrm{z}+1.488$ \\
\hline F & -0.1 & 1.45 & F-G & $\mathrm{z}(\mathrm{y})=-0.1$ \\
\hline G & -0.1 & 1.65 & G-H & $\mathrm{y}(\mathrm{z})=1.65$ \\
\hline
\end{tabular}




\begin{tabular}{|c|c|c|c|c|}
\hline Points & $\mathrm{Z}, \mathrm{m}$ & $\mathrm{Y}, \mathrm{m}$ & $\begin{array}{c}\text { Boundary } \\
\text { points of line }\end{array}$ & Analytic function \\
\hline $\mathrm{H}$ & 0.0 & 1.65 & $\mathrm{H}-\mathrm{I}$ & $\mathrm{y}(\mathrm{z})=1.65$ \\
\hline $\mathrm{I}$ & 0.1 & 1.65 & $\mathrm{I}-\mathrm{J}$ & $\mathrm{z}(\mathrm{y})=0.1$ \\
\hline $\mathrm{J}$ & 0.1 & 1.45 & $\mathrm{~J}-\mathrm{K}$ & $\mathrm{y}(\mathrm{z})=-0.384^{\star} \mathrm{z}+1.488$ \\
\hline $\mathrm{K}$ & 0.225 & 1.402 & $\mathrm{~K}-\mathrm{L}$ & $\mathrm{z}(\mathrm{y})=0.225$ \\
\hline $\mathrm{L}$ & 0.225 & 0.65 & $\mathrm{~L}-\mathrm{M}$ & $\mathrm{y}(\mathrm{z})=0.65$ \\
\hline $\mathrm{M}$ & 0.17625 & 0.65 & $\mathrm{M}-\mathrm{N}$ & $\mathrm{y}(\mathrm{z})=5.817^{\star} \mathrm{z}-0.375$ \\
\hline $\mathrm{N}$ & 0.15 & 0.4973 & $\mathrm{~N}-\mathrm{O}$ & $\mathrm{z}(\mathrm{y})=0.15$ \\
\hline $\mathrm{O}$ & 0.15 & 0.0 & $\mathrm{O}-\mathrm{P}$ & $\mathrm{y}(\mathrm{z})=0$ \\
\hline $\mathrm{P}$ & 0.0 & 0.0 & $\mathrm{P}-\mathrm{A}$ & $\mathrm{y}(\mathrm{z})=0$ \\
\hline
\end{tabular}

Notes: The coordinates of the points are given according to Fig. 3.

The symmetry of the points is shown with the orange and blue background.

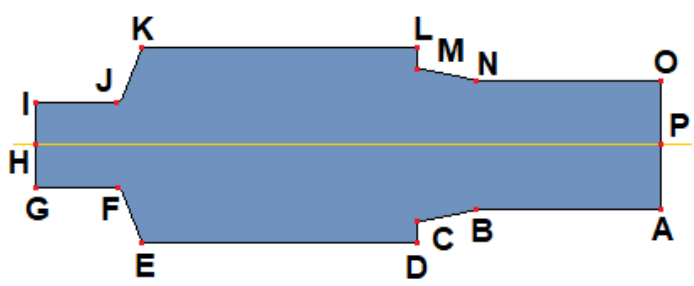

Figure 5- Geometric analysis of the $E$ target (turn $90^{\circ}$ counterclockwise)

Puc. 5 - Геометрический анализ фригуры $E$ (повёрнута на угол $90^{\circ}$ против часовой стрелки)

Слика 5-Геометријска анализа мете E (окренуте супротно од правца казаљке на сату за $\left.90^{\circ}\right)$

The contour of the E shooting target (the UCL (EFGHIJK) and the $B C L$ (DCBAPONML) (Fig. 5)) can be described by a piecewise function:

$$
C L_{\mathrm{E}}(z)=\left\{\begin{array}{c}
U C L_{\mathrm{E}}(z)=\left(\begin{array}{cc}
0.384 z+1.488 & -0.225 \leq z<-0.1 \\
1.65 & -0.1 \leq z<0.1 \\
-0.384 z+1.488 & 0.1 \leq z \leq 0.225
\end{array}\right) \\
B C L_{\mathrm{E}}(z)=\left(\begin{array}{cc}
0.65 & -0.225 \leq z<-0.176 \\
-5.817 z-0.375 & -0.176 \leq z<-0.15 \\
0 & -0.15 \leq z<0.15 \\
5.817 z-0.375 & 0.15 \leq z<0.176 \\
0.65 & 0.176 \leq z \leq 0.225
\end{array}\right) .
\end{array}\right.
$$

The $K$ target has the smallest area. The silhouette and the geometry of the target are shown in Fig. 6. 

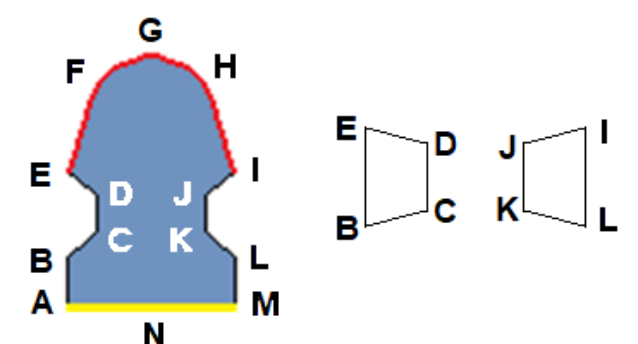

Figure 6-Geometric constituent parts of the K target (see Fig. 3)

Фиг. 6-Геометрические составляющие мишени К (см. рис. 3)

Слика 6-Геометријски елементи мете К (видети слику 3)

The hit probability of this target can be found as an algebraic subtraction of the hit probabilities of its three domains

$$
P_{\text {hitK }}=P_{\text {hit }}(A B E F G H I L M)-P_{\text {hit }}(B E D C)-P_{\text {hit }}(K J I L) \text {. }
$$

The coordinates of the vertices of the $K$ target as a geometric figure and the analytical functions of its sides are collected in Table 5.

Table 5-K shooting target: coordinates of the points

Таблица 5- Координаты точек контура мишени типа $\mathrm{K}$

Табела 5- Координате тачака контуре мете типа K

\begin{tabular}{|c|c|c|c|c|}
\hline Points & $\mathrm{Z}, \mathrm{m}$ & $\mathrm{Y}, \mathrm{m}$ & $\begin{array}{l}\text { Boundary } \\
\text { points of line }\end{array}$ & Analytic function \\
\hline A & -0.11 & 0.0 & $A-B$ & $z(y)=-0.11$ \\
\hline $\mathrm{B}$ & -0.11 & 0.0652 & $\mathrm{~B}-\mathrm{C}$ & $y(z)=0.795^{\star} z+0.153$ \\
\hline C & -0.0714 & 0.0959 & C-D & $z(y)=-0.0714$ \\
\hline $\mathrm{D}$ & -0.0714 & 0.1458 & D-E & $y(z)=-0.795^{\star} z+0.089$ \\
\hline$E$ & -0.11 & 0.1765 & $E-F$ & $y(z)=2.883^{*} z+0.494$ \\
\hline $\mathrm{F}$ & -0.0714 & 0.2878 & $\mathrm{~F}-\mathrm{G}$ & $\mathrm{y}(\mathrm{z})=\mathrm{S}_{1}(\mathrm{z})$ \\
\hline $\mathrm{G}$ & 0.0 & 0.33 & G-H & $y(z)=S_{2}(z)$ \\
\hline $\mathrm{H}$ & 0.0714 & 0.2878 & $\mathrm{H}-\mathrm{I}$ & $y(z)=-2.883^{\star} z+0.494$ \\
\hline 1 & 0.11 & 0.1765 & I-J & $y(z)=0.795^{\star} z+0.089$ \\
\hline $\mathrm{J}$ & 0.0714 & 0.1458 & $\mathrm{~J}-\mathrm{K}$ & $z(y)=0.0714$ \\
\hline $\mathrm{K}$ & 0.0714 & 0.0959 & $\bar{K}-\mathrm{L}$ & $y(z)=-0.795^{\star} z+0.153$ \\
\hline $\mathrm{L}$ & 0.11 & 0.0652 & L-M & $z(y)=0.11$ \\
\hline $\mathrm{M}$ & 0.11 & 0.0 & $\mathrm{M}-\mathrm{N}$ & $y(z)=0$ \\
\hline $\mathrm{N}$ & 0.0 & 0.0 & $\mathrm{~N}-\mathrm{A}$ & $y(z)=0$ \\
\hline \multicolumn{5}{|c|}{ 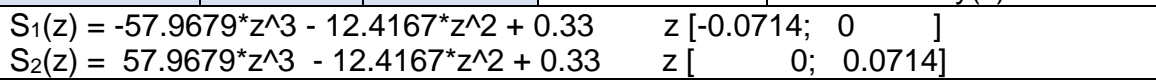 } \\
\hline
\end{tabular}

The piecewise functions $C L$ for the $K$ target are determined below. 
$C L_{\text {all }}(z)= \begin{cases}U C L_{\text {all }}(z) & \left.=\begin{array}{ll}2.883 z+0.494 & -0.11 \leq z<-0.0714 \\ -57.9679 z^{3}-12.4167 z^{2}+0.33 & -0.0714 \leq z<0 \\ 57.9679 z^{3}-12.4167 z^{2}+0.33 & 0 \leq z<0.0714 \\ -2.883 z+0.494 & 0.0714 \leq z<0.11\end{array}\right) \\ B C L_{\text {all }}(z)=\left(\begin{array}{ll}0 & -0.225 \leq z \leq 0.225\end{array}\right) & \end{cases}$

$$
C L_{\mathrm{BEDC}}(z)=\left\{\begin{array}{l}
U C L_{\mathrm{BEDC}}(z)=(-0.795 \cdot \mathrm{z}+0.089-0.11 \leq z \leq-0.0714) \\
B C L_{\mathrm{BEDC}}(z)=(0.795 \cdot \mathrm{z}+0.153-0.11 \leq z \leq-0.0714)
\end{array}\right.
$$

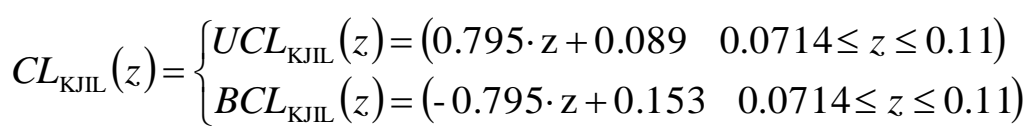

The sequence steps - the development of the calculation program in the CAS Mathcad will be described in the next section.

\section{Calculation in the CAS Mathcad}

The projectile horizontal range (in meters) is defined in the Mathcad as a range of variable $x$ with the initial value of 50 , the end value of 400 and the increment of 51 (the step size is 1 meter)

$$
x:=50,51 . .400 \text {. }
$$

The text below shows the usage of the variable range to define the values of the vectors $\sigma y$ and $\sigma z$ (eqs. 7 and 8 ) which characterize the bullet dispersion in the vertical and lateral directions

$$
\begin{aligned}
& \sigma y_{x}:=5.935 \cdot 10^{-4} \cdot x, \\
& \sigma z_{x}:=2.967 \cdot 10^{-4} \cdot x,
\end{aligned}
$$

and the values of the vectors my and $\mathrm{mz}$ (eqs. 5 and 6) (which assign the $P O I$ location according to the MBT with the zero range at 300 meters)

$$
\begin{gathered}
m y_{x}:=a-0.029+1.969 \cdot 10^{-3} \cdot x-2.645 \cdot 10^{-6} \cdot x^{2}-1.192 \cdot 10^{-8} \cdot x^{3} ; \\
a:=0 ; \quad m z_{x}:=-1.667 \cdot 10^{-5} \cdot x+1.667 \cdot 10^{-7} \cdot x^{2}
\end{gathered}
$$


Using the constant $a$, the my vector can be displaced vertically in the up-down direction. If $a>0$, then the zero range increases $(>300 \mathrm{~m})$. Usually, $a$ is equal to 0 (zero range $=300 \mathrm{~m}$ ). Thus, the parameter a makes it possible to simulate the position of the $P O A$ along the height of the shooting target.

For each value of $x$, set the $x^{\text {th }}$ element of the vector variables $\sigma y$ and $\sigma z$, and $m y$ and $m z$ with a corresponding value of $x$. The tables of numbers for the vector variables $\sigma y, \sigma z$ and $m y, m z$ are of the same size. Each of them consists of 351 numbers. Using the variables sYi and sZi, we determine the center of the shooting target. For the $K$ target, its center will be defined as (sYK, sZK). For the $H$ target, as (sYH, sZH), and so on. The data on the position of the centers of the $K, H, G, F$, and $E$ targets are shown in Table 6 (in meters).

Table 6 - Coordinates of the shooting target centers

Таблица 6-Координаты центра стрелковых мишеней

Табела 6-Координате центара мета за гађање

\begin{tabular}{|c|c|c|c|}
\hline Number & $\begin{array}{c}\text { Type (kind) } \\
\text { of targets }\end{array}$ & $\begin{array}{c}\text { Center height } \\
\text { coordinates, } m\end{array}$ & $\begin{array}{c}\text { Center coordinates in } \\
\text { width, } m\end{array}$ \\
\hline 1 & $\mathrm{~K}$ & $\mathrm{sYK}=0.165$ & $\mathrm{sZK}=0$ \\
\hline 2 & $\mathrm{H}$ & $\mathrm{sYH}=0.165$ & $\mathrm{sZH}=0$ \\
\hline 3 & $\mathrm{G}$ & $\mathrm{syG}=0.275$ & $\mathrm{sZG}=0$ \\
\hline 4 & $\mathrm{~F}$ & $\mathrm{syF}=0.5$ & $\mathrm{sZF}=0$ \\
\hline 5 & $\mathrm{E}$ & $\mathrm{syE}=0.825$ & $\mathrm{sZE}=0$ \\
\hline
\end{tabular}

For the $K$ target, the following expression can be proposed:

$P_{\text {hitK }}=P_{\text {hit }}(A B E F G H I L M)-P_{\text {hit }}(B E D C)-P_{\text {hit }}(K J I L)=P_{\text {hit }} A-P_{\text {hit }} L-P_{\text {hit }} R$,

here $P_{\text {hit }}(A B E F G H I L M), P_{\text {hit }} A$ - probability of hitting the ABEFGHILM domain as a function of the PHR; $\mathrm{P}_{\text {hit }}(\mathrm{BEDC}), \mathrm{P}_{\text {hit }} \mathrm{AL}$ - probability of hitting the BEDC domain as a function of the PHR; $\mathrm{P}_{\text {hit }}(\mathrm{KJIL}), \mathrm{P}_{\text {hit }} \mathrm{R}-$ probability of hitting the KJIL domain as a function of the PHR.

Due to the conditional operator if, the UCL and the $B C L$ of the constituent elements for the $K$ shooting target are defined as:

$$
U C L_{\text {all }}(z)=\left(\begin{array}{ll}
2.883 z+0.494 & \text { if }(-0.11 \leq z<-0.0714) \\
-57.9679 z^{3}-12.4167 z^{2}+0.33 & \text { if }(-0.0714 \leq z<0) \\
57.9679 z^{3}-12.4167 z^{2}+0.33 & \text { if }(0 \leq z<0.0714) \\
-2.883 z+0.494 & \text { if }(0.0714 \leq z<0.11)
\end{array}\right)
$$




$$
\begin{gathered}
B C L_{\text {all }}(z)=(0 \quad \text { if }(-0.225 \leq z \leq 0.225)), \\
U C L_{\mathrm{BEDC}}(z)=(-0.795 \cdot \mathrm{z}+0.089 \quad \text { if }(-0.11 \leq z \leq-0.0714)), \\
B C L_{\mathrm{BEDC}}(z)=(0.795 \cdot \mathrm{z}+0.153 \quad \text { if }(-0.11 \leq z \leq-0.0714)), \\
U C L_{\mathrm{KJIL}}(z)=(0.795 \cdot \mathrm{z}+0.089 \quad \text { if }(0.0714 \leq z \leq 0.11)), \\
B C L_{\mathrm{KJIL}}(z)=(-0.795 \cdot \mathrm{z}+0.153 \quad \text { if }(0.0714 \leq z \leq 0.11)) .
\end{gathered}
$$

The assessment of the hit probabilities of the elements of the $K$ target is realized by the following formulas

Phit_A $A_{x}:=\int_{-0.225}^{0.225} \int_{B C L_{\text {all }}(z)}^{U C L_{\text {all }}(z)}\left[\frac{1}{2 \pi \sigma z_{x} \sigma y_{x}} \cdot \exp \left[-\left[\frac{\left[z-m z_{x}\right]^{2}}{2\left(\sigma z_{x}\right)^{2}}+\frac{\left[y-m y_{x}\right]^{2}}{2\left(\sigma y_{x}\right)^{2}}\right]\right] d y d z\right.$

Phit_L $L_{x}:=\int_{(-0.11)}^{(-0.0714)} \int_{(0.795 \cdot z+0.153)}^{(-0.795 \cdot z+0.089}\left[\frac{1}{2 \pi \sigma z_{x} \sigma y_{x}} \cdot \exp \left[-\left[\frac{\left[z-m z_{x}\right]^{2}}{2\left(\sigma z_{x}\right)^{2}}+\frac{\left[y-m y_{x}\right]^{2}}{2\left(\sigma y_{x}\right)^{2}}\right]\right] d y d z\right.$

Phit_ $R_{x}:=\int_{(0.11)}^{(0.0714)} \int_{(0.795 \cdot z+0.153)}^{(-0.795 \cdot z+0.089)}\left[\frac{1}{2 \pi \sigma z_{x} \sigma y_{x}} \cdot \exp \left[-\left[\frac{\left[z-m z_{x}\right]^{2}}{2\left(\sigma z_{x}\right)^{2}}+\frac{\left[y-m y_{x}\right]^{2}}{2\left(\sigma y_{x}\right)^{2}}\right]\right] d y d z\right.$

For the $U C L$ of the $H, G$ and $F$ target silhouettes, there are the expressions

$$
\begin{gathered}
U C L_{H}(z):=\mid \begin{array}{l}
(0.384 z+0.1684) \text { if }(-0.225 \leq z<-0.1) \\
(0.33) \text { if }(-0.1 \leq z<0.1) \\
(-0.384 z+0.1684) \text { if }(0.1 \leq z \leq 0.225)
\end{array} \\
U C L_{G}(z):=\mid \begin{array}{l}
(0.384 z+0.388) \text { if }(-0.225 \leq z<-0.1) \\
(0.55) \text { if }(-0.1 \leq z<0.1) \\
(-0.384 z+0.388) \text { if }(0.1 \leq z \leq 0.225)
\end{array}
\end{gathered}
$$




$$
U C L_{F}(z):=\mid \begin{aligned}
& (0.384 z+0.838) \text { if }(-0.225 \leq z<-0.1) \\
& (1.0) \text { if }(-0.1 \leq z<0.1) \\
& (-0.384 z+0.838) \text { if }(0.1 \leq z \leq 0.225)
\end{aligned} \text {. }
$$

Finally, the UCL $\left(U C L_{E}(z)\right)$ and the $B C L\left(B C L_{E}(z)\right)$ of the $E$ target silhouettes are designed by the formula:

$$
\begin{gathered}
U C L_{E}(z):=\mid \begin{array}{l}
(0.384 z+1.488) \text { if }(-0.225 \leq z<-0.1) \\
(1.65) \text { if }(-0.1 \leq z<0.1) \\
(-0.384 z+1.488) \text { if }(0.1 \leq z \leq 0.225)
\end{array} \\
B C L_{E}(z):=\mid \begin{array}{l}
(0.65) \text { if }(-0.225 \leq z<-0.176) \\
(-5.817 z-0.375) \text { if }(-0.176 \leq z<-0.15) \\
(0) \text { if }(-0.15 \leq z<0.15) \\
(5.817 z-0.375) \text { if }(0.15 \leq z<0.176) \\
(0.65) \text { if }(0.176 \leq z \leq 0.225)
\end{array}
\end{gathered}
$$

The hit probability assessment for the $H$ target is

$$
\begin{aligned}
P_{h i t-H_{x}:=} \int_{-0.225}^{0.225} \int_{0}^{U C L_{H}(z)}\left[\frac { 1 } { 2 \pi \sigma z _ { x } \sigma y _ { x } } \cdot \operatorname { e x p } \left[-\left[\frac{\left[z-m z_{x}\right]^{2}}{2\left(\sigma z_{x}\right)^{2}}+\right.\right.\right. \\
\left.\left.+\frac{\left[y-m y_{x}\right]^{2}}{2\left(\sigma y_{x}\right)^{2}}\right]\right] d y d z .
\end{aligned}
$$

The formulas for the $G$ and $F$ targets are given in the appendix of this paper. The hit probability assessment for the $E$ target is

$$
P_{h i t} E_{x}:=\int_{-0.225}^{0.225} \int_{B C L_{E}(z)}^{U C L_{E}(z)}\left[\frac { 1 } { 2 \pi \sigma z _ { x } \sigma y _ { x } } \cdot \operatorname { e x p } \left[-\left[\frac{\left[z-m z_{x}\right]^{2}}{2\left(\sigma z_{x}\right)^{2}}+\right.\right.\right.
$$




$$
\left.\left.+\frac{\left[y-m y_{x}\right]^{2}}{2\left(\sigma y_{x}\right)^{2}}\right]\right] d y d z .
$$

\section{Results of the calculation}

The curves characterizing the hit probabilities functions of five different types of targets $(K, H, G, F$, and $E)$ that were determined using the MBT (5) are shown in Fig. 7. The space under the curve in the interval $50-400 \mathrm{~m}$ is highlighted in yellow. For all five targets, the $P O A$ (red square) was the same location - the middle of the BCL. The shooting conditions were considered to be ideal.

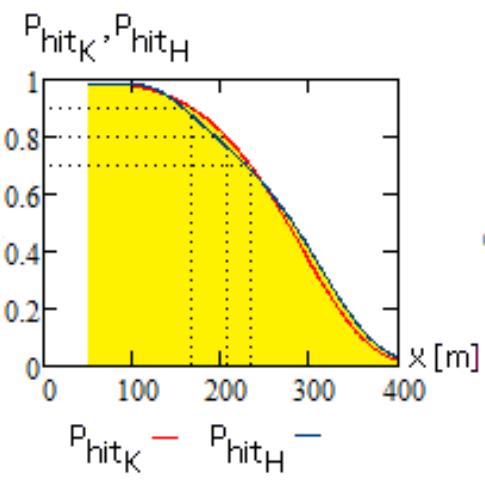

a)

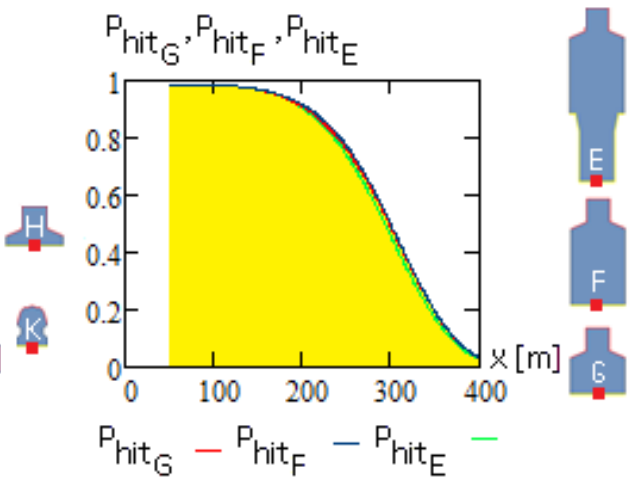

b)

Figure 7 - Hit probability vs the PHR for the $K$ and $H$ targets (a) and the $G, F$, and $E$ targets (b) for the range of 50-400 $\mathrm{m}$

Pис. 7- Функции вероятности попадания в мишени К, Н и мишени $G, F, E$ для дистанций 50-400 м

Слика 7-Функције вероватноће погодака мета K, H и мета G, F, E на растојању od 50 до $400 \mathrm{M}$

The hit probability change vs the $P H R$ for all five targets is a classical decreasing curve (Shereshevskiy et al, 1979). The dashed lines in Fig. 7a show the ranges that correspond to the hit probabilities of 0.9 , 0.8 , and 0.7 for the $K$ target.

Changing the shape for the hit probability vs the $P H R$ with respect to the $F$ target and the location of the POA (red square) is shown in Fig. 8. 


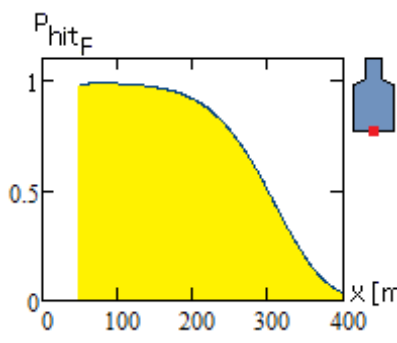

a)

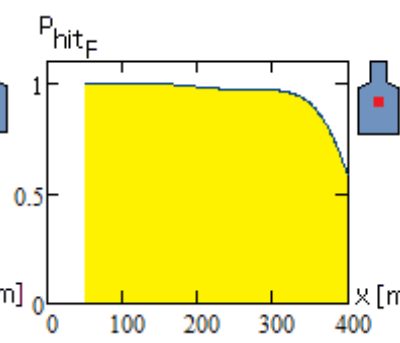

b)

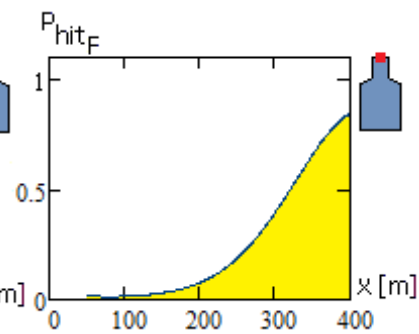

c)

Figure 8 - Hit probability vs the location of the POA for the $F$ target for the range of 50 $400 \mathrm{~m}$

Puc. 8- Вероятности попадания в мишени F для дистанций 50-400 м и положения точки прицеливания

Слика 8- Вероватноће погодака мете F на растојању од 50 до 400 м и положаја тачке нишањења

Fig. 8 shows that if the range to the shooting target is 200 meters and if the $P O A$ is positioned on the $B C L$ (see the red square as the graphical symbol), then the hit probability is 0.92 (Fig 8a). If the $P O A$ is $0.5 \mathrm{~m}$ higher, then the hit probability for the $P H R=200 \mathrm{~m}$ is increased to be 0.98 (Fig. 8b). If the POA is increased to 1.0 meters, then the hit probability decreases to 0.08 . Thus, if the distance to the shooting (real) target is known as well as the target geometric dimensions and the ballistic characteristics of the bullet flight path (MBT and bullet dispersion), the $P O A$ determining algorithm for a remote weapon station of a ground combat vehicle can be proposed.

\section{Conclusions and Implications}

This paper represents a method for assessing the single shot hit probability for a stationary (fixed) shooting target as a function of the $P H R$, the selected target type and the location of the POA. The proposed procedure has three blocks. The proposed method is built on a modular basis and allows a user to change types of weapons and types of shooting targets.

The single shot hit probability depends on five variables: height of the POI; lateral displacement of the POI relative to the target; bullet dispersion in the height (vertical direction); lateral bullet dispersion (horizontal direction); and the forms of the shooting target contour. To order these variables, three auxiliary quantities can be introduced. These are the projectile horizontal range $(P H R)$, the altitude of the point of aim 
and the lateral displacement of the point of aim. The last two variables can be combined into the "POA location».

For demo calculations, the external ballistics and the bullet dispersion characteristics of the $5.45 \times 39$ Kalashnikov assault rifle model MPi AK-74N were selected. Five types of Swiss military targets imitating OPFOR combatant silhouettes were used as shooting targets. For illustrating the operability of the proposed method, the hit probability for the $K, H, G, F$, and $E$ shooting targets was evaluated as well as for the $P H R$ from 50 to $400 \mathrm{~m}$. The calculations have shown that the PHR and the form of the target cause a complex dependence between the $P_{h i t}$ and the shooter-target distance.

The developed mathematical model can be used in tactical computer interactive simulators that emulate combat situations of a tactical strike. Likewise, the proposed mathematical models of shooting targets can be used for improving digital target range simulators or in firecontrol systems of remote weapon stations.

\section{Appendix}

Formulas for the hit probability assessment of some shooting targets

The hit probability $P_{h i t}$ vs the $P H R$ for the $G$ and $F$ targets can be expressed as

$$
\begin{aligned}
& P_{h i t} G_{x}:=\int_{-0.225}^{0.225} \int_{0}^{U C L_{G}(z)}\left[\frac { 1 } { 2 \pi \sigma z _ { x } \sigma y _ { x } } \cdot \operatorname { e x p } \left[-\left[\frac{\left[z-m z_{x}\right]^{2}}{2\left(\sigma z_{x}\right)^{2}}+\right.\right.\right. \\
& \left.\left.+\frac{\left[y-m y_{x}\right]^{2}}{2\left(\sigma y_{x}\right)^{2}}\right]\right] d y d z \\
& P_{h i t} F_{x}:=\int_{-0.225}^{0.225} \int_{0}^{U C L_{F}(z)}\left[\frac { 1 } { 2 \pi \sigma z _ { x } \sigma y _ { x } } \cdot \operatorname { e x p } \left[-\left[\frac{\left[z-m z_{x}\right]^{2}}{2\left(\sigma z_{x}\right)^{2}}+\right.\right.\right. \\
& \left.\left.+\frac{\left[y-m y_{x}\right]^{2}}{2\left(\sigma y_{x}\right)^{2}}\right]\right] d y d z
\end{aligned}
$$




\section{References}

http://weaponland.ru/load/avtomat_shturmovaja_vintovka_serii_mpi_k_mpi ak/10-1-0-31. (in Russian). Accessed: 20.06.2018.

http://www.wikiwand.com/en/Shooting_target. Accessed: 20.06.2018.

Khaikov, V.L. 2018. Single shot hit probability estimation as a result of a numerical solution of double integrals using Mathcad. Vojnotehnički glasnik/Military Technical Courier, 66(4), pp.739-756. Available at: https://doi.org/10.5937/vojtehg66-17433.

-NVA der DDR. 5.45-mm-Maschinenpistole AK74 und leichtes Maschinengewehr RPK74. Beschreibung und Nutzung1985 (in German).

Peelen, J. 2017. There is more to short barrels than just velocity. [Internet]. Available at: www.quarryhs.co.uk/shortbarrel2.pdf. Accessed: 20.06.2018.

Rodney, S. 2012. RPG encounter modeling. SURVIAC Bulletin, 27(1), pp. 1-5.

Svateev, V.A. 2013. Avtomatchik dolzhen i mozhet porazhat' golovnuyu figuru. Bulletin of the Academy of Military Sciences, 43(2), pp.127-131 (in Russian). (In the original: Сватеев B.A. 2013. Автоматчик должен и может поражать головную фригуру, Вестник академии военных наук, №.2(43). C.127-131).

Svateev, V.A. 2014. Tochniy sposob raschota veroyatnosti popadaniya v figurnuyu tsel'. Bulletin of the Academy of Military Sciences, 49(4), pp.61-66 (in Russian). (In the original: Сватеев B.A. 2014. Точный способ расчёта вероятности попадания в фригурную цель, Вестник Академии военных наук. 2014. T.49, № 4. C.61-66.)

-TRADOC. 1975. Range and lethality of US and Soviet anti-armor weapons.

-TRADOC. 2015. Worldwide Equipment Guide, Ground Systems. Vol. 1.

Venttsel' Ye.S. 2006. Teoriya veroyatnostey. Moscow: Vysshaya shkola (in Russian). (In the original: Вентцель Е.С. 2006. Теория вероятностей. Москва: Высшая школа).

Wollschläger, D. 2017. Analyzing shape, accuracy, and precision of shooting results with shotGroups. [Internet] Available at: https://cran.rproject.org/web/packages/shotGroups/vignettes/shotGroups.pdf. Accessed: 20.06.2018.

МЕТОДИКА ОЦЕНКИ ВЕРОЯТНОСТИ ПАПАДАНИЯ ОДИНОЧНЫМ ВЫСТРЕЛОМ КАК ФУНКЦИЯ ГОРИЗОНТАЛЬНОЙ ДАЛЬНОСТИ С УЧЁТОМ ВИДА СТРЕЛКОВОЙ МИШЕНИ И ПОЛОЖЕНИЯ ТОЧКИ ПРИЦЕЛИВАНИЯ

Вадим Л. Хайков,

независимый исследователь, г. Краснодар, Российская Федерация

ОБЛАСТЬ: прикладная математика, исследование операций

ВИД СТАТЬИ: оригинальная научная статья

ЯЗЫК СТАТЬИ: английский 
Резюме:

Оценка вероятности попадания является важной частью процедуры анализа эфрфективности стрельбы. B cmaтье предложен метод оценки вероятности попадания в статическую стрелковую мишень как фрункция горизонтальной дальности до мишении (ГДМ), её типа и положения точки прицеливания. Предлагаемая процедура оценки состоит из трех частей. Часть I посвящена двойной интегральной фрормуле с учётом изменений в местоположении средней точки попадания (СТП) на поверхности мишени в зависимости от ГДМ. Характеристики дисперсии пуль в зависимости от ГДМ определены в части II. Основой части I и части II является двумерное некоррелированное распределение вероятностей Лапласа-Гаусса. Как правило, фрункции ординат (абсцисс) СТП от аргумента ГДМ и ффункции ординат (абсцисс) рассеивания пули как фуункции ГДМ представлены в виде классических полиномов. В части III даётся описание контура мишени. В математическом плане контур цели является кусочной фоннкцией, которая описывает верхний и нижний края стрелковой мишени, а во-вторых, контур иели в фрормуле двойного интеграла выступает как предел интегральной формулы части I. Bce вычисления реализованы в PTC Mathcad. Предлагаемый метод построен на модульной основе и позволяет пользователю изменять типы оружия и виды мишеней. Для демонстрационных расчётов использованы данные характеризующие внешнюю баллистику и характеристики рассеивания 5.45×39 автомата Калашникова. В качестве рассматриваемой модели автомата была выбрана MPi AK-74N. В качестве стрелковых мишеней использовались пять видов швейцарских армейских мишеней, которые имитируют различные части силуэта комбатанта. Для иллюстрации работоспособности предложенного метода оценена вероятность попадания в мишени $K, H, G, F, E$ и для диапазона ГДМ от 50 до 400 м.

Ключевые слова: вероятность попадания, численное решение, стрелковая мишень, двойной интеграл, рассеивание пуль, горизонтальная дальность, Mathcad.

ОДРЕЂИВАЊЕ ВЕРОВАТНОЋЕ ПОГОТКА ЈЕДНИМ ХИЦЕМ У ЗАВИСНОСТИ ОД ХОРИЗОНТАЛНЕ РАЗДАЉИНЕ, РАЗЛИЧИТИХ ВРСТА МЕТА И ПОЛОЖАЈА ТАЧКЕ НИШАЊЕЊА

Вадим Л. Хајков

независни истраживач, Краснодар, Руска Федерација

ОБЛАСТ: примењена математика, операциона истраживања ВРСТА ЧЛАНКА: оригинални научни чланак ЈЕЗИК ЧЛАНКА: енглески 
Сажетак:

У чланку је представљена метода за одређивање вероватноће поготка стационарних мета у зависности од хоризонталног растојања до мете (XPM), врсте мете и локације тачке циља. Предложени поступак састоји се од три блока. Први блок се бави формулом двоструког интеграла која узима у обзир промене у локацији тачке поготка у зависности од ХРМ. Карактеристике дисперзије метка, у зависности од ХРМ, одређују се у другом блоку. Биваријантна некорелисана Гаус- Лапласова расподела вероватноће узета је за основ прва два блока. Функције локације тачке циља (ордината/апциса) у зависности од XРM и фрункције карактеристика дисперзије погодака у зависности од XРM приказане су у облику полинома. У трећем блоку наведен је опис контура силуета мета. У математичком смислу, контура мете је хибридна функција која дефинише горње и доње ивице мете и, такође, представља границу формуле двоструког интеграла првог блока. Сви прорачуни су се вршили у PTC Mathcad. Предложени метод заснован је на модуларном принципу и омогућава кориснику да мења врсте оружја и мета. За илустрацију је изабран приказ израчунавања карактеристика дисперзије поготка који је постигнут из аутоматске пушке „калашњиков”, калибра 5.45×39, модел MPi AK-74N. За мете је изабрано пет типова швајцарских војних мета које имитирају различите делове силуете војника. Операбилност предложеног метода илустрована је одређивањем вероватноћа погађања мета K, H, G, F u E на удаљености од 50 до 400 м.

Кључне речи: вероватноћа поготка, нумеричко решавање, мета за гађање, двоструки интеграли, дисперзија погодака, хоризонтално растојање, Mathcad.

Paper received on / Дата получения работы / Датум пријема чланка: 06.08.2018. Manuscript corrections submitted on / Дата получения исправленной версии работы / Датум достављања исправки рукописа: 26.11.2018.

Paper accepted for publishing on / Дата окончательного согласования работы / Датум коначног прихватања чланка за објављивање: 28.11.2018.

(c) 2019 The Author. Published by Vojnotehnički glasnik / Military Technical Courier

(www.vtg.mod.gov.rs, Втг.мо.упр.срб). This article is an open access article distributed under the terms and conditions of the Creative Commons Attribution license

(http://creativecommons.org/licenses/by/3.0/rs/).

(c) 2019 Автор. Опубликовано в «Военно-технический вестник / Vojnotehnički glasnik / Military Technical Courier» (www.vtg.mod.gov.rs, втг.мо.упр.срб). Данная статья в открытом доступе и распространяется в соответствии с лицензией «Creative Commons»

(http://creativecommons.org/licenses/by/3.0/rs/).

(c) 2019 Аутор. Објавио Војнотехнички гласник / Vojnotehnički glasnik / Military Technical Courier (www.vtg.mod.gov.rs, втг.мо.упр.срб). Ово је чланак отвореног приступа и дистрибуира се у складу са Creative Commons лиценцом (http://creativecommons.org/licenses/by/3.0/rs/). 